\author{
Michal Červinka, Lenka Švajdová \\ Department of marketing and value creating processes \\ Business School Ostrava, plc., Check Republic \\ Tomáš Tykva \\ Department of business and management \\ Business School Ostrava, plc., Check Republlic \\ UDC: $338.483 .11 / .12(437.3)$
}

\title{
THEMATIC TOURISM VS. MASS TOURISM IN THE CZECH REPUBLIC
}

\begin{abstract}
The article titled Thematic Tourism vs. Mass Tourism in the Czech Republic is concerned with the relationship between thematic tourism, mass tourism and presuppositions of the tourism development. The authors aim is to compare the turnout of thematic tourism attractions and sights focused on mass tourism paying attention to presuppositions of the tourism development and barriers for the turnout of thematic monuments. Comparisons will be based on presuppositions of tourism development and will be based especially on the specifics of thematic tourism - as a marginal field within the tourism industry. The application part will focus on the comparison of sights with massive turnout in the Czech Republic and thematic landmarks as the subject of thematic tourism. Special attention
\end{abstract}

\section{Introduction}

At the beginning of the third millennium tourism has undoubtedly become one of the most powerful and most dynamically developing economic sector. Its permanent place among the human being activities is demonstrated by the fact that, despite various war conflicts, natural disasters and epidemics, it has neither perished, nor its volume declined; yet it increased again in the aftermath of the threat. In the Czech Republic foreign tourism represents the market share of $2.7 \%$ of GDP (the figure from 2012), which is not a negligible value as a result of the economy will be paid to the comparison of the two most visited monuments in the Czech Republic as for mass tourism - the Charles Bridge, and the most visited monument as for thematic tourism - the hydro-power plant Dlouhé Stránè, a technical representative of thematic tourism. Both monuments were elected by general public on the list of Seven Wonders of the Czech Republic in 2013. The aim is to confirm / refute the hypothesis that quality preconditions of tourism development are essential for the development of tourism and visiting tourist attractions. The article will use secondary data analysis methods and author's own field research.

Key words: thematic tourism, mass tourism, comparison of sights, the Check Republic

mainly based on heavy industry. The Czech Republic has significant assumptions for tourism development not only due to its location in the heart of Europe, but also for its attractiveness in the form of natural beauties and cultural and historic amenities. (MMR, 2013)

\section{Statement of the problem}

\section{Mass vs. Individual Tourism}

Tourism was originally considered to be another term for travel. It is now associated with the use of free time, excursions 
and recreation. Some authors also define it as a specific form of mechanical movement of the population, with growing extent and intensity. (Hrala, 2001)

There are many kinds of tourism, for example recreational, cultural, adventure, but also mass and thematic tourism. The increase in the development of mass tourism occurred around the 1970s, when a significant development in the use of air transport appeared as an ideal way of rapid movement of people from point $A$ to $B$, whereas the high speed of travel was a basic characteristic of what we called mass tourism. For even greater expansion, then it was at the turn of the $20^{\text {th }}$ and $21^{\text {st }}$ century, when, together with the changes in political settlement in Europe and the expansion of low-cost airlines, the development of mass tourism started. In consequence of the predominance of offer over demand and the market oversaturated with the "classic" range of offers from the operators of tourism occurring in the last 10 years in relation to the development of thematic tourism, some of the attributes of the characteristics of mass tourism are evident; however, thanks to its ability to respect better the wishes and needs of customers, it is becoming a highly demanded product on the part of the individual travelers in many cases. (Hrala, 2001).

In the professional literature innumerable forms of tourism are mentioned. For the purposes of this article, the authors will continue to pay attention to the characteristics of the tourism according to the number of participants. According to the number of participants tourism is divided into four basic groups. The participants in each form of tourism present similar characteristics. The aforementioned groups are as follows: individual tourism, group tourism, mass tourism and environmental tourism. According to the demographic-sociological characteristics the closest are the tourists who are in the groups of individual and environmental explorers; on the opposite side there are the participants of mass and group tourism (Rygalová, 2011). Figure 1 shows the layout of different forms of tourism on a scale from 0 to 100 , depending on the number of participants, their behaviour during travel within the meaning of the mode of transport used, length of stay and respect for local culture in the place of residence.

Figure 1: The Forms of tourism

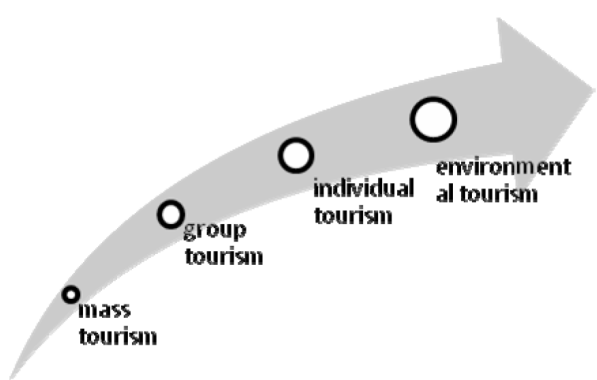

Source: Authors

Due to the focus of the article, the authors will continue with the topic of the characteristics of mass and individual tourists. This corresponds best to the process of thematic tourism with its characteristics.

As it has already been mentioned above, a participant of mass tourism looks for socalled fast means of transport, mainly air transport. One of the reasons is to maximize the number of days spent in a destination (the average length of stay is four and a half days). The program of the traveller of mass tourism is fixed and managed externally, mostly by travel agents or tour operators. In their destination they are mostly passive, even though in most cases they never miss to visit the most significant cultural monuments.

At the place where they spend their holidays, they prefer to search the elements of an imported lifestyle, which put a stop to the recognition of local gastronomy, culture, etc. Their intellectual preparation or surveys on the site of destination, where they are going to spend their vacations is minimal. Among the destination residents they are perceived 
as noisy with the feeling of superiority in the places where they are spending their holidays.

In contrast, an individual tourist, who is in most cases a participant in the thematic tourism, has in many ways different characteristics. Participant of the individual tourism does not mind to spend longer time on his way to a final destination; in contrast, he views it as an opportunity to learn something extra. On his journey he usually reserves a relatively longer period of time, usually about 2-3 weeks. If possible he is trying to respect the way of life typical for the country, looking for experiences associated with the activity that he wants to develop on his holiday. He devotes enough time when preparing for his holiday. Destination residents, among whom he is staying, see him as quiet and tactful. Table 1 presents basic differences between mass and individual tourists, as the representatives of the mass or thematic tourism (Palátková, 2011).

Table 1: Basic differences between mass and individual tourists

\begin{tabular}{|c|c|}
\hline Mass tourist & Individual tourist \\
\hline $\begin{array}{l}\text { - Little time } \\
\text { - Small or no intellectual preparation } \\
\text { - No foreign languages } \\
\text { - Feeling of dominancy } \\
\text { - Shopping } \\
\text { - Souvenirs } \\
\text { - Postcards } \\
\text { - Curiosity } \\
\text { - Noisiness }\end{array}$ & $\begin{array}{l}\text { - Enough time } \\
\text { - Suitable slow transport } \\
\text { - Spontaneous decision coming from outside } \\
\text { - Experination country lifestyle } \\
\text { - Busy and active } \\
\text { - Preparation before travel } \\
\text { - Foreign languages } \\
\text { - Joy of cognition } \\
\text { - Small presents } \\
\text { - Memories, notes, new piece of knowledge } \\
\text { - Taking photos, drawing, painting } \\
\text { - Behaviour } \\
\text { - Stillness }\end{array}$ \\
\hline
\end{tabular}

Source: Authors

In order to better understand the difference between mass and thematic tourism, it is necessary to recall the definition of a tourism destination, which can be generally understood as the place where people are travelling in order to obtain some experience. It is a set of products and services that are consumed by the visitors on behalf of the inclusive brand or tag. It is the range of products, services and, last but not least, the quality level of expectations of tourism development that increase or decrease the competitiveness - in other words a visit rate of a particular destination. The higher the concentration of tourist attractions within a specific tourism destination is, the higher the assumption is that it will be more tourist-oriented one. And here is a synergistic effect - if tourists spend, in most cases, not low amounts, they are trying to make this investment the most effective. For tourist destinations, which have not a high number of tourist attractions, the situation is more complex, because here the tourists will always consider whether they will visit such destinations or not. Logically, in the first case it will be a tourist destination visited by tourists, especially mass; by contrast, in the 
second case it will be a destination where the individual visitor is going with a particular goal.

\section{Industrial attractiveness of destination}

Whether and to what extent the destinations will be frequented depends on a number of factors, inter alia, also what type of sights/ tourist attractions are in it. For the purposes of this article, it is necessary to define the concept of technical attraction/monument from a monolingual dictionary of tourism such as "the attractiveness of tourism structure, technical equipment or technical solutions to unique or interesting in its processing, relations to the surrounding buildings, size, historic or current signification, design, etc. and the present is the goal for the visitors (e.g. bridges, tunnels, water and wind mills, mining towers, railway viaducts, water canals)". The great advantage of technical monuments is the fact that unlike castles and chateaus there are not a static background, but they live by what people dream up in order to achieve progress. However, it should be noted that generally technical monuments are not most attractive for tourists. Typically, the most frequent visitors to these sites are scholars, students, and public whose motives for the visits to these objects are different from the motivational factors in traditional tourism. They are primarily cognitive and educational themes. The problem with marketing management of technical monuments is primarily to identify causes which prevent people from visiting these destinations, where the main attraction is just a technical monument. Among the fundamental barriers that may prevent a potential visit the following are included: practical ones (physical accessibility, awareness and information about the place, price, the amount of free time); furthermore, psychocultural barriers (the perceived relevance of offers and interest, perception (image) of destinations to a potential user, cultural competence of the visitor). When offering technical monuments as tourist attractions attention should be paid to ensure the optimum availability of such monuments, and the availability of the physical, but also the sensorial one. (Kesner, 2005).

The visit to technical monuments is the choice of certain leisure options that are available to individuals or groups concerned. People generally invest their limited time and limited financial funds to such free time activities which combine some real benefits. For technical monuments in this context, the most often resolved is a range of admission. In relation to the limited available resources, and, in particular, in conjunction with other barriers, this may deter many potential visitors, which constitutes a reason for a thoughtful pricing policy. The final decision is also affected by the image of the destination. The image can be defined as a complex of a mental construction, which a person creates on the basis of all the information, knowledge, experience and previous experience of the concrete cultural facilities or directly on a specific destination and the value of the experience, which he or she gets (Kesner, 2005).

The potential tourist must feel the right size of motivation when visiting monuments. For technical monuments the motivation for their visit is often very closely distanced, consciously specified and planned for a long time before. Visiting the "classic" monuments may be rather a visit based on the uncertain motivation, unclear and rather incidental. It mixes needs, but also the values, interests and beliefs of the man and, of course, these are often the result of crossing personal motivation and the dynamics of social groups in which a visit takes place.

\section{Conditions of tourism development}

In relation to tourism the conditions of tourism development have a secondary 
meaning. They occupy the decisive position in a specific location in the time of vacations / journey realization. They express the ability of the landscape to provide values for different forms of tourism, and they also decide about the use of the area of tourism in terms of natural conditions, the attractiveness and social options. Location conditions only create certain assumptions, whose use in tourism is subject to selective and implementation assumptions.

Mainly, they have a primary position in the development of tourism. The conditions document the eligibility of residents to participate in tourism. The society assumptions for tourism development predetermine economic and cultural level and also the political situation. Only through the selective factors conditions can be used for tourism in the particular area. These are opposed to the location conditions (Hara, 2008).

Implementation conditions (Vystoupil, 2006; Drobná \& Morávková, 2004) create certain connections between places of interest for recreation (e.g. big cities), and places where people want to recreate (spa, mountain, cultural, historical and other areas). They allow vacationers to make claims in places where conditions are favourable. Tourists can get to these places and use them to stay and spend their leisure time. These conditions are of two types - material-technical and transporting conditions, which will be closer discussed in this paper.

Material-technical conditions represent the devices, thanks to which the development of tourism in the area is allowed and supported. These facilities include accommodation, catering, sports, entertainment, cultural, sports and recreation, and also transport equipment (cable cars, ski lifts), which is used for recreation. Number of visitors in these objects is limited by their capacity.

Under transport conditions we understand transport network and the means of transport, which are on the move. These are among the essential conditions for the devel- opment of tourism. The quality and density of the traffic network in the area is especially important. The availability of tourist destination with transport is better, along with the growing possibility of tourists' prosperity (Hara, 2008).

Transport availability is very closely linked with tourism development. Better transport infrastructure in a particular region means better traffic availability of individual sites that are in it. The degree of accessibility has a considerable importance in the selection of tourist destinations that people visit. An important role is played by what the road and rail networks are, and also the presence of international airports on the territory of the Czech Republic.

Transport accessibility can be understood as "the ability to reach a particular place on the surface of the Earth with the help of the means of transport. In particular, the distance is affected by location, speed and frequency of connections, the quality of transport services, reliability, and pricing ranges. "

The concept of availability can be understood also as the ease with which we can achieve the objective of the space with the use of any transport system (Hara, 2008).

\section{Image of tourist attractiveness and its visit rate}

The life cycle of a destination represents a theoretical model of the development of tourist destinations, which is a variant of the general product life cycle curve used in marketing. Further it suggests a relationship between the image of the destination in the eyes of current and potential visitors, and the level of the visit rate. While the image of tourist attractiveness is the basic element of the tourist destination, the visit rate is rather closely related to the development of destinations. The development of destinations can be monitored on the basis of selected indicators, for example viable capacity of des- 
tination, status and the potential of tourism (growth of the number of visitors and their average expenditure, growth in the share of development costs, promotion, etc.) According to various authors, the life cycle of a destination is made up of different numbers of phases; the problem is to be found in its own territorial delimitation of the destination and in difficult elimination of many external factors.

The theory operates with 6 stages of the life cycle of tourism destination:

1. Phase of exploration (discovering destinations): smaller numbers of visitors come disorganized to the destination that prefer individual forms of tourism, and are attracted by unique natural and cultural phenomena, in order to intensively explore the local culture. Due to the lack of tourist infrastructure, they use the existing private resources, mutual contact of visitors and residents is intense, and visitors are favourably accepted by the destination community. The physical or social environment of destinations is affected only minimally.

2. Phase of destination involvement: increase in the volume and regularity of visits; starting a business in tourism; the beginning of the promotion; symptom of seasonality; the beginning of the organisation and cooperation with local authorities and other institutions; commercialization of an intensive contact with visitors and residents; visitors are admitted primarily positively and neutrally.

3. Phase of development: activities of local operators and original equipment are more pushed by modern devices in the ownership of the external (often foreign) entities; the development of the promotion of tourist attractions; the commercialization of the original attractions, the emergence of new attractions, inauthenticity; changes in the physical form of destination; impacts on the social environment and ecology; change in the lifestyle of residents; the highest value of visitation; during the tourist season the predominance of visitors over residents; the prevailing attitude of residents to visitors is tolerance and apathy; the attitude of the visitors to the residents - the distance, indirect contact, only a commercial motivation.

4. Phase of consolidation: slowing down the pace of the visit rate increase; the high dependence of the local economy on tourism; the gradual establishment of a tourist ghetto; mass tourism with a destination as a "tourist paradise"; visitors without interest in the real life of residents (contingency tourism); dissatisfaction and irritation of residents with a range of tourism; adaptation of the residents to the presence and activities of visitors; the decline of the visit rate and popularity of destinations for overpopulation.

5. Phase of stagnation: a decline in the average length of stay and spending of visitors; unwanted and irreversible changes in the environment; the predominance of the established clientele and conference tourism; even in a season of fully unused capacity; authentic attractions gradually squeezed out with artificial; the decline in the attractiveness of destinations attached to its genuineness; the increase in antagonistic attitudes of local residents to visitors and to the development of tourism.

6. Phase of post-stagnation: four possible forms of this phase: decline (gradual attenuation of the tourist function associated with the overcrowded destination, with insufficient investment and innovation, with a reduction in the quality of the environment, with the degradation of life style, with the loss of genius loci), stabilization (maintaining a stable level of visitation), reduced growth (new offer adapted to the capacity of the destination, a slight increase in visit rate), rejuvenation (changing the image of the destination, to increase the capacity of the territory using the viable innovations, new technologies and effective methods of management, new increase in visit rate). (Pásková, 2008). (See Chart 1). 
Chart 1: Tourism Lifecycle.



Source: $h t t p: / / w w w . t h e s e e r c o m p a n y . c o m / c o m p a n y /$

\section{Methods}

In order to create the following paper, the method of the literature search and expert articles have been applied. Further, we have analyzed the expert studies. With the view of confirming the hypothesis, diagnostic mission methods have been used along with the vertical analysis of selected indicators, as well as the primary research method - the questionnaire survey was conducted among respondents. The quota selection has been applied. With the aim of creating the final part of the article, synthetic and deductive procedures have been applied too.

\section{Solving problem}

\section{Classic vs. industrial destination}

According to the nationwide poll, which involved 1,213,362 respondents, the aforementioned sites ranked first, the Charles Bridge that occupied the first place with 106
601 of the preferential votes, followed then with 105603 votes by Dlouhé Stráně (HydroPower Plant). The first 7 places are represented by attractions that can be characterized as historical monuments, technical monuments and natural attractiveness (idnes.cz).

The ranking of the first two positions reflects the uniqueness of the individual monuments in their area. However, if we focus on the visit rate of the individual monuments tourists left in the case of the two monuments to other numerical values, the Charles Bridge number will be significantly higher and will reflect the favourable conditions for the development of tourism in Prague. The total number of visitors and tourists will be cutting the number of visitors/tourists who visit Prague every year. In the case of Dlouhé Stráně, the situation will be reversed. In recent years this monument has been visited by 40 thousand people per year. The causes of this relatively small visit, considering the significance of this technical monument, is certainly a great number. If we put aside the general conditions of the tourism develop- 
ment, which are in the area of the MoravianSilesian Region, and the area of the Jeseníky Mountains pathetic, then probably another cause can be a barrier, which the visitor can feel at different times, prior to the visit of this technical monuments.

The causes of the situation described above are a few, but the main striking differences in the conditions for the development of tourism are the following: localization, implementation and selective conditions of tourism development as well as the above mentioned barriers to visits to technical monuments.

\section{Defining the conditions for the development of the Charles Bridge destination}

The Charles Bridge is the second oldest stone bridge in the Czech Republic. The foundation stone of the building was laid in 1357, on the foundations of the featured Judith's Bridge. It was demolished in 1342 by the destructive floods. As it is evident from the name itself, the Emperor Charles IV was accountable for the construction of the bridge. The bridge, which in the past was represented an important connection between the Old Town of Prague and the Little Quarter, was completed in 1402.

The Charles Bridge is located in Prague, the capital city of the Czech Republic. Prague as a political, geographical and administrative centre of the Czech Republic and the main tourist destination in a very good location meets both the implementation and localization conditions for the development of tourism. There is a good connection with Prague on the important road and rail transport networks of the Czech Republic as well as with other major cities in neighbouring European countries (Slovakia, Poland, Austria, Germany). These include the presence of Prague Václav Havel Airport, where the total number of passengers in 2013 was 10
807 890, for low-cost carriers to haul 2654 216 passengers (Prague Airport, 2012).

These figures make Prague come first as for the visit rate of tourist destinations in the Czech Republic - 5.4 million visitors in 2012. This is the estimated figure of tourists who visited the Charles Bridge (Prague Welcome, 2013). This is the estimated number that is derived from statistical data on persons staying in Prague and surroundings, because the nature of the monuments cannot get accurate statistical data.

Thanks to the long-term influx of Czech and foreign tourists Prague has an extensive range of facilities that are parts of the material and technical conditions. There is a broad and diverse network of quality accommodation and catering facilities, a dense network of entities that provide ancillary services to the tourism industry.

If we characterize the selective development of tourism, in Prague we will meet with a number of factors, which will decline the selective conditions of tourism development. Prague has a reputation as a tourist destination, where tourists could face many dangers - taxi drivers who charge more, pickpockets, dishonest behaviour of the workers in money exchangers and generally low language skills; a large number of tourists in Prague are among the most common concerns on the part of visitors too. If we assess the barriers to visit this monument, then it will be very small. The Charles Bridge has a positive image between Czech and foreign tourists, and this fact is reflected in the high visit rate of this monument, as well as in the high evaluation of the sights from the perspective of its uniqueness and image.

If we are to characterize the phase of the life cycle of tourism destination, Prague is currently in the $3^{\text {rd }}$ and $4^{\text {th }}$ phase. Currently, there is neither the decreasing pace of the increase in the visit rate, nor the high dependence of the local economy on tourism is evident. With gradual establishment of a tourist ghetto, mass tourism with the 
destination as a "tourist paradise", is evident too. However, to the detriment of Prague, marketing activities are beginning to address market segments that are the providers of tourism services generating a sufficient profit. Unfortunately, it also spoils the image of Prague as a tourist destination suitable for seniors and families with children. We can see the increase in the number of visitors evident without an interest in the real life of residents (contingency tourism), dissatisfaction and irritation of residents with a range of tourism, adaptation to the residents of the presence and activities of visitors, the decline in visit rate and popularity of destinations for overpopulation.

\section{Defining the conditions for the development of the Dlouhé Stráně (hydro-power plant) destination}

Industrial heritage and technical attractions include all the attractions which in recent years have been given increasingly greater attention and become the drivers of visit rates to tourist destinations. Just to illustrate this: the Hydro-Power Plant of Dlouhé Stráně had its visit rate of about 80 000 tourists in 2013 (Čez, 2014).

The pumped storage plant of Dlouhé Stráně which is located in the Hrubý Jeseník, has three "best ofs". It is the largest reverse hydro turbine in Europe with the performance nominal power of $325 \mathrm{MW}$. At the same time it is a plant with the largest declivity in the Czech Republic, that is $510.7 \mathrm{~m}$ and it is also the power plant with a maximum installed total power capacity in the Czech Republic - 2 x 325 MW.

The plant uses a half-kilometre height decline between the dam and reservoir on the river of Divoká Desná hollow on the top of Mravenečník hill at an altitude of 1350 metres. In 1978 the hilltop was aligned and was dug out of the upper reservoir power stations with a total volume of $2.72 \mathrm{~m}^{3}$. The flooded area with the maximum level is 15.4 ha. Since 1996, 650-MW power plant has been used (Čez, 2014).

Figure 1: Hydro-power plant of Dlouhé Stránè.

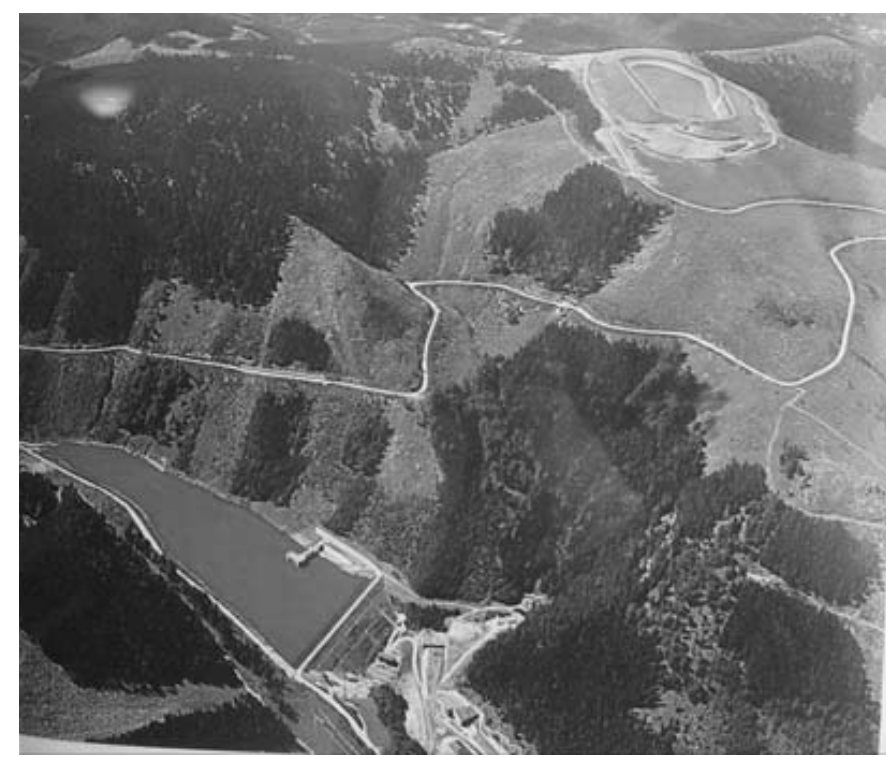

Source: http://www.dlouhe-strane.cz/strane/fotogalerie 
Dlouhé Stráně is situated in Moravia in the region of Olomouc, specifically in the area of the Jeseníky Mountains. The region of Olomouc is by virtue of the city of Olomouc a relatively known tourist destination. However, to the detriment of this region, the number of visitors and not even of the foreigners has dropped. The reason should be low level of long-term conditions for the development of tourism.

If the selective conditions for the development of tourism would be characterized, the above characterized monument comes here in contrast. Minimum attention is paid to the region of Olomouc, and especially to the area of Jeseníky, by the state authorities whose competence is the development and promotion of tourist destinations. The area of Jeseníky is a popular tourist destination during the winter months; unfortunately, out of the main ski season it is a relatively neglected destination for tourists.

The reason may be the fact that in the closer distance from Dlouhé Stráně there are a number of other tourist attractions, such as Velké Losiny with its castle and the factory producing the handmade paper or the Spa of Karlova Studánka. Thus it has all the conditions to become an attractive tourist destination. Unfortunately, none of the tourist attractions belongs to tourist targets with a large cultural or historical significance.

In the framework of the implementation of the tourism development conditions the assumptions of the material-technical and transport are included. In the field of material-technical conditions, this area is struggling with a lack of high-quality and modern accommodation facilities, which provide services to which visitors are accustomed to from other sectors. In the area of provision of catering services, the situation is very similar.

In the area of implementation conditions as well as in the field of transport, the situation is bad. There is a missing fast connection to the backbone of the highway D1, along with building a minimum speed communication. There is no good railway connection with Ostrava and Olomouc. For these reasons, the availability of this monument is very complicated not only for the Czechs, but primarily for foreign visitors, too. The foreigners should spend a long way and a lot of money to visit this monument coming from Prague. In the neighbouring region, an airport - Letiště Ostrava is located. However, it offers a minimum number of regular lines. In 2013 the Ostrava Airport offered scheduled flights to London, Moscow, Paris, as well as to Croatian Split in the summer months). These regular flights carried 91,062 passengers in 2012 (Ostrava Airport, 2013).

If we assess the barriers for a visit to this monument, they would be larger in comparison with the mass visited Charles Bridge. Among the most important barriers is the fact that this is a technical monument, which in principle raises concerns among the visitors rather than the expected benefit. Another barrier may occur in the physical availability of sights just after the evaluation of the implementation of tourism development conditions.

Within the life cycle of the tourist destination, Dlouhé Stráně and its surroundings, are situated at the interface between the second and the third phases. According to the long-term statistics there is an increase in the volume and regularity of visitors. In recent years there has been a significant improvement in cooperation with the local government and other institutions, which ensure the development of tourism. The development and emergence of new attractions rarely occur. The main cause is primarily a vaguely defined long-term concept for the development of tourism. This fact causes the reluctance of investors to invest in this area which is a significant barrier that prevents potential entrepreneurs from developing their activities in the field of tourism. 


\section{The outputs of the primary research}

The results of the questionnaire research are the result of the survey, which was carried out in the period from November 2013 to January 2014. As a method for the realization of the research method the personal respondents were selected. The respondents were selected by the polling form of unrepresentative techniques appropriate to the occasion. The sample consisted of students of various consultation centres of Ostrava Business School plc. The size was 187 of the respondents, of which 105 were women, 82 men. In terms of the geographic segmentation 60 respondents were from the region of Olomouc, 90 respondents from the Moravian-Silesian region, 17 from the Slovak Republic and 20 from the Central Bohemia region.

The aim of the survey was to compare the conditions for tourism development of tourist attractiveness of the Charles Bridge (Prague), as a representative of mass tourism and the hydro-power plant of Dlouhé Stráně (Jeseníky), as a representative of the thematic tour focussing on technical monuments.

From the total of 187 respondents the transport availability of the Charles Bridge sight was rated very good by $86 \%$ of respondents. Those who responded negatively came from towns or villages, which lie outside the main railway track Slovakia - Ostrava - Olomouc - Pardubice - Prague. Approximately $72 \%$ of those who rated the availability as very good, visited the Charles Bridge and Prague, too. For technical monuments of Dlouhé Stráně only 32\% of the respondents judged the availability of transport as very good, $44 \%$ as good and as very bad $34 \%$ of the respondents. Among the respondents who expressed negatively there were those interviewed from the Slovak Republic and the Central Bohemia region. Then it would be repeatedly visited by only $31 \%$ of the total $72 \%$ who rated the availability of sights as very good and good.
From the total of 187 respondents $98 \%$ of the respondents evaluated the material and technical conditions of the Charles Bridge as very good. For technical monuments Dlouhé Stráně $49 \%$ of respondents judged materially-technical conditions as very good, $21 \%$ as good and as very poor $3 \%$ of respondents, $27 \%$ of the total number of respondents have never visited Dlouhé Stráně tourist destination yet. The availability of high-quality accommodation in a higher category seems to be problematic for the respondents who visited Dlouhé Stráně.

From the total of 187 respondents 98\% of the respondents evaluate the objective selective conditions for the Charles Bridge as very good. Technical monuments of Dlouhé Stráně were rated positively and the objective selective conditions as very good by $37 \%$ respondents, as good by $41 \%$ and very bad by $22 \%$ of the respondents. In the case of subjective selective conditions, according to the subjective author's expectations there was a balanced ratio between the answers at the Charles Bridge and technical monuments of Dlouhé Stráně. Both attractions were rated as very well by about $40 \%$, as it is good by about $35 \%$, and as very bad by around $25 \%$. In the case of the Charles Bridge the cause of the negative evaluation was fear of large number of people. In the case of the power plant Dlouhé Stráně there were some concerns of too much expertise, the application of the interpretation and the simple fact that this is a technical monument.

\section{Discussion}

The survey results confirmed the hypothesis that the quality conditions for tourism development are prerequisites for the development of tourism and tourism attractions. According to the results of exploration, specifically the availability of transport is considered as the most fundamental assumption of the realization on the part of tourists. 
At the same time, a partial hypothesis has confirmed the need to support tourism as a specific regional policy instrument. The promotion of tourism in the region of Olomouc is not effective and the funds are often spent without the evaluation of the longterm impact on the development of tourism in a particular region.

\section{Conclusion}

On the basis of the methods described in the previous text, the character of tourist attractions together with the conditions for the tourism development has affected the visit rate of a tourist destination to a large extent. Moreover, the fact is that the tourist destination will be sorted according to the category of mass tourism destinations, or rather will be classified to the group of thematic tourism destinations. The Charles Bridge accomplishes a high degree of quality conditions for the development of tourism - excellent transport accessibility, quality of the material-technical conditions and minimum barriers for the visitors when considering potential visits. As for technical monuments such as the Hydro Power Plant of Dlouhé Stráně, we can expect that they will always be more frequented by individual tourists who look for thematically focused tourist attractions. In the case of Dlouhé Stráně one of the reasons will be the fact that the conditions for the development of tourism in this area are not at a sufficient level. The hypotheses provided by the authors of the article have been confirmed, i.e., the quality conditions of tourism development are a prerequisite for the development of tourism and tourism attractions. The hypothesis in relation to the need to promote tourism as well as to a specific regional policy instrument has also been confirmed. The issue is very broad, and in the context of the next survey we should focus on other destinations. For more precise results the number of respondents should be expanded, or the portfolio of the surveyed entities ought to be extended too. On the basis of this research it was possible to define our own model of the creditworthiness of a tourist destination, which will be portable and usable for any destination, regardless of the geographic and thematic focus.

\section{References}

Butler, R. W. (1980) The Concept of a Tourism Area Cycle of Evolution: Implication for Management of Resources. Canadian Geographer, No. 24, vol. 1.

Hara, T. (2008) Quantitative Tourism Industry Analysis: Introduction to Input-Output, Social Accounting Matrix Modelling and Tourism. Oxford: Elsevier, Inc.

Hrala, V. (2001) Geografie cestovního ruchu. Praha: Idea Servis.

Kesner, L. (2005) Marketing a management muzeí a památek. Praha: Grada.

Morávková, E \& Drobná, D. (2004) Cestovní ruch. Praha: Fortuna.

Palátková, M. \& Zichová, J. (2011) Ekonomika turismu - Turismus České republiky. Praha: Grada.

Páskalová, M. (2008) Udržitelnost rozvoje cestovního ruchu. Hradec Králové: Gaudeamus.

Ryglová, K., Burian, M. \& Vajčnerová, I. (2011) Cestovní ruch - podnikatelské principy a př́ležitosti v praxi. Praha: Grada.

Vystoupil, J. (2007) Marketing cestovního ruchu. Brno: Masarykova univerzita, Ekonomicko-správní fakulta.

\section{Reports and websites:}

idnes.cz: ANON. (2005) Čtenáři iDNES zvolili sedm divů Česka. Idnes.cz. [Online] Available from: http://zpravy.idnes.cz/ctenari-idnes-zvolili-sedm-divu-ceska-dwx-/domaci.aspx?c=A050826_131632_domaci_ton 
Prague Welcome, 2013: ANON. (2010) Praha ve statistikách. [Online] Available from: http://www.praguewelcome.cz/cs/infocentrum-b2b/info-servis/praha-ve-statistikach/

Ostrava Airport, 2013: ANON. (2013) Annual Report 2012. Ostrava Airport. [Online] Available from:

http://www.airport-ostrava.cz/UserFiles/ File/Vyrocni_zpravy/VZ\%202012(1).pdf

ČEZ, 2014: ANON. (n.d.) Na Dlouhé Stráně dorazilo přses 80000 turistü. [Online] Available from:

http://www.cez.cz/cs/pro-media/tiskovezpravy/4533.html
Prague Airport, 2012: Krejčí, E. (2013) Zájem cestujicích o Prahu trvá, potvrzuji to přepravní výsledky Letiště Václava Havla Praha za rok 2012. [Online] Available from: http://www.prg.aero/cs/o-letisti-praha/ tiskove-centrum/tiskove-zpravy/zajemcestujicich-o-prahu-trva-potvrzuji-to-prepravni-vysledky-letiste-vaclava-havla-praha-za-rok-2012/

MMR 2013: Conceptual report of the Ministry for Regional Development of the Czech Republic (n.d.). [Online] Available from: http://www.mmr.cz/getmedia/50770b7d9700-4b63-83da-1fc4320f9b14/Predkladaci-zprava-ke-Koncepci.pdf 
